GEOGRAFICKÝ ČASOPIS / GEOGRAPHICAL JOURNAL 73 (2021) 4, 347-358

DOI: https://doi.org/10.31577/geogrcas.2021.73.4.18

\title{
WATER RETENTION OF THE ORGANIC SOIL HORIZON IN A CENTRAL EUROPEAN DECIDUOUS FOREST
}

\author{
Anton Zvala*, Peter Šurda*, Anna Kidová**, Justína Vitková* \\ * Institute of Hydrology, Slovak Academy of Sciences, Dúbravská cesta 9, 84104 Bratislava, Slovakia, \\ zvala@uh.savba.sk, surda@uh.savba.sk,vitkova@uh.savba.sk \\ ** Institute of Geography, Slovak Academy of Sciences, Štefánikova 49, Bratislava, Slovakia, \\ geogkido@savba.sk
}

\begin{abstract}
Water retention of the organic soil horizon in a central European deciduous forest

The organic horizon of forest soil (OHFS) under deciduous forest is formed on the surface of the forest soil and is composed of a varied dead plant and animal material. This material gradually decomposes into recognizable layers of OHFS: litter, duff-1 and duff-2. Different soil water retention (SWR) can be expected from different layers of the OHFS. The determination of SWR was performed on the Tempe cells and pressure plate apparatus. We analyzed the SWR in the layers litter, duff-1, duff- 2 of the OHFS. Statistically significant differences between all three examined layers of forest soil were examined. The analysis of the individually determined soil water retention curves (SWRC) proved that the litter layer of the OHFS had a maximal SWR at a water potential close to zero and a minimal value was estimated for the duff-2 layer. According to the results of our experiment the SWR decreases with the increasing depth of the organic horizon in the order litter $>$ duff- $1>$ duff- 2 . We determined potential areas with geographically similar conditions for the creation of the OHFS for SWR as in the study area.
\end{abstract}

Key words: organic horizon of forest soil, deciduous forest, soil water retention, Tempe cells, pressure plate apparatus, geotope, Železná studnička

\section{INTRODUCTION}

Forest soil contains an organic and a mineral component. On the surface of the forest soil is an organic component, which forms the organic horizon of forest soil (hereafter referred to as OHFS). The vegetation species composition determines the creation of OHFS with various physical and chemical properties and influences the structure of the OHFS. The structure of OHFS plays an important role in forest soil water retention (further on SWR). Organic material containing the OHFS forms the conditions for SWR, the formation of soil aggregates and porosity. The development of organic material decomposition processes has an influence on SWR in the OHFS (Rasoulzadeh and Ghoorabjiri 2014, Li et al. 2015 and Ilek et al. 2017). Research of soil organic matter is a demanding discipline due to various continuous and parallel transformation processes, which cause its highly variable overall biochemical composition and habitus in the whole spectrum of spatial scales (Sato et al. 2004).

The hydrological importance of the OHFS is due to its control over the transfer of water and energy between the sub-canopy atmosphere and the mineral soil (Zagyvai-Kiss et al. 2019). The relief geomorphology, subsoil hydrogeology, climatic conditions and water balance of a forest highly affects the SWR of the OHFS (Minár et al. 2001). It is necessary to emphasize also the importance of the research of the SWR in soil as a phenomenon influencing the hydrological cycle and its output for the assessment of flood /drought hazard. 
The transfer of water from the surface to the deeper soil horizons is influenced by soil permeability and by substrate and soil properties (texture and structure). Together with the SWR, they determine the hydrological consequences of maximum precipitation or flow. The type of land use and runoff coefficients are the basis for the research of eco-stabilization properties (Hanušin and Lacika 1997 and Hanušin 2002). Another possibility of how to hold the water in the land is to build artificial water reservoirs.

We define SWR as water captured in soil for a long time. Gravitational water drains, but capillary water remains in the soil kept by capillary forces. The range of SWR is different for each soil type. Water retention of soil is determined by the soil water retention curve (SWRC). The SWRC represents the relationship between soil water content and pressure head (Velebný et al. 2000) and together with hydraulic conductivity is the most important characteristic for the study of water dynamics in the soil (Jonczak 2013 and Ilek et al. 2017.).

Forest soil has greater SWR than meadows and cultivated soils (Leuschner 1998 and Gajic et al. 2008). The OHFS protects soil aggregates from the erosion of raindrops and prevents the release of clay and muddy particles from the soil pores. This plays an important role in soil and water protection (Zhang et al. 2016).

The maximum runoff during flood events was about 1.5 times greater than the range observed before the removal of the organic component of the forest soil. The removal of the organic component from forest soil can reduce SWR and increase maximum flow, especially during relatively large floods (Gomyo and Kuraji 2016). Research in Slovakia has mostly focused on the forest as a complex system, which retains water (Čaboun and Mind'áš 2003, Holko et al. 2009 and Caboun et al. 2010). Several authors have also studied the influence of the OHFS on SWR (Heiskanen and Makitalo 2002, Greiffenhagen et al. 2006, Li et al. 2014, Gomyo and Kuraji 2016, Hlaváčiková et al. 2016, Zvala et al. 2018, Dlapa et al. 2020 and Zhu et al. 2020).

The objective of this study was: a) to determine the SWR of OHFS of deciduous central European forest using laboratory experiments (the Tempe cells equipment and pressure plate apparatus); b) statistical analysis of measured data and determination of differences in SWRC and c) identifying potential areas with geographically similar conditions.

\section{MATERIALS AND METHODS}

\section{Study area}

The selected study area for research of SWR in the OHFS was Železná studnička in Bratislava with a deciduous forest (Fig. 1a). The study area is part of the Bratislava Forest Park at the end of Mlynská Dolina Valley in the Malé Karpaty Mts. The borders of the study area mostly coincide with the southern border of the Protected Landscape Area Malé Karpaty. From the northeast the area is bordered by the capital city of the Slovak Republic, Bratislava. The study area is formed by the southern part of the Male Karpaty Massif. In the east it is bordered by the Podunajská nížina lowland, in the west by the Záhorská nížina lowland. The highest peak of the Malé Karpaty mountain range is Záruby $(768 \mathrm{~m}$. a. s. 1.). In the study area there is the highest peak Kamzík (439.4 m. a. s. 1. - Fig. 1b). The valleys and various depressions that separate the plateaus have formed mostly in tectonically 


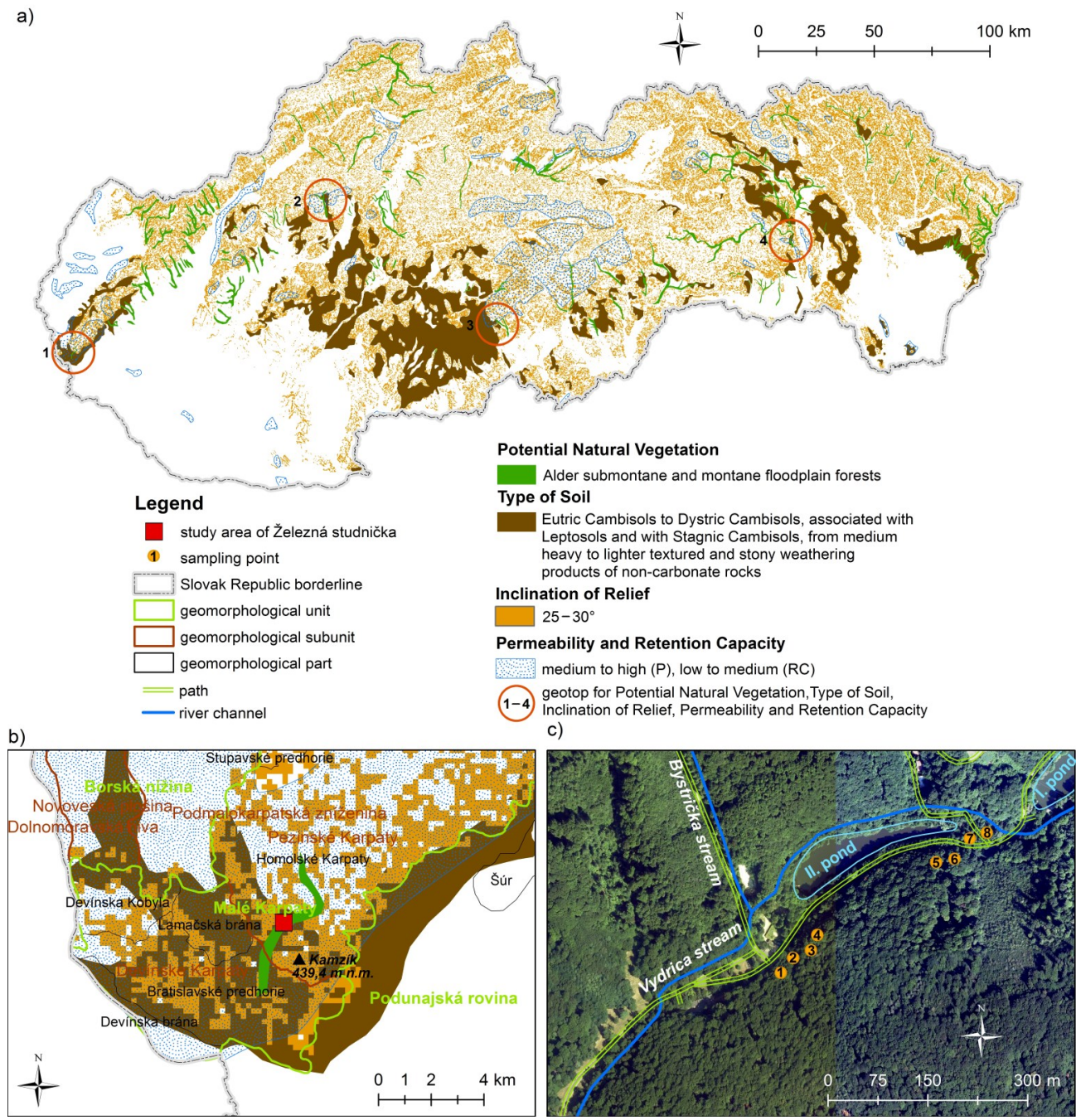

Fig. 1. (a) Study area of Železná studnička located in the context of specific soil and vegetation conditions of Slovakia. Geomorphological unit-subunit-part of four identified geotopes: 1. Malé Karpaty-Pezinské Karpaty-Homolské Karpaty 2. Strážovské VrchyZliechovská hornatina-Temešská vrchovina 3. Ostrôžky/Revúcka vrchovina-x/Cinobanské predhorie-x/Lovinobanská brázda 4. Čierna hora-Hornádske predhorie-x (Atlas krajiny SR 2002). Symbol " $x$ " represents no further differenced geomorphological division in hierarchical level. (b) Geomorphological character of the study area: 25-30 inclined relief

with typical Eutric Cambisols with medium to high permeability and low to medium retention capacity. (c) Spatial distribution of the eight sampling points near the recreational facility of Železná studnička.

Background image: (C) Institute of Geodesy and Cartography, National Forestry Center (2017-2019). 
predisposed places. The valleys in the upper parts, corresponding to the level of the plateaus, have a valley river profile with a slight slope. In the lower parts of the mountains, they pass into deeper-cut valleys in the shape of an open letter "V" without a river floodplain or only with a poorly developed river floodplain (Maglocký 2002) with an inclination of about $20^{\circ}$. Towards the foot of the mountains, the valleys deepen more and more with a slope of $25-30^{\circ}$ (Zvara and Gašpar 2002). The study area is classified as a moderately rugged highland. Its peripheral zones are the lowland type of landscapes.

The altitude of research points ranges from 220 to 228 meters above sea level. The average annual temperature of the area is $8-9^{\circ} \mathrm{C}$ and the average rainfall is in the range of $600-700 \mathrm{~mm}$ (Lapin et al. 2002). The study area is dominated by plant species of the Carpathian foothills with an occurrence of lowland thermophilic species. The following habitats were classified in the study area according to the Catalogue of Habitats of Slovakia (Stanová and Valachovič 2002): beech and fir-beech flower forests, acid-loving beech forests, oak-hornbeam forests of the Carpathians, drought and acid-loving oak forests, ash-alder foothill floodplain forests, forests linden - maple rubble forests.

Within the study area the experimental sampling points were set on the forest slopes with different depths of organic horizon. The sampling points were placed along the way from the Železná studnička recreational facility to the rising spring near to pond II. Sampling of the organic horizon was carried out in the year 2017. The soil cover of the sampling point sites is created from Eutric Cambisols to Dystric Cambisols, associated with Leptosols and with Stagnic Cambisols, with a medium heavy to light texture and with stony weathering products of non-carbonate rocks (Śály and Surina 2002). The loess clays and sand walls occur locally as part of the slope system. Sampling points $1,2,3$ and 4 with a $30^{\circ}$ inclination were near the Železná studnička recreational facility (Fig. 1c). This sampling point is characterized by a very deep organic horizon with mixed layers of plant litter. Sampling points 5,6 with $25^{\circ}$ and 7,8 with $30^{\circ}$ inclination were located near the rising spring pond II (a system of artificial ponds on the Vydrica stream) outside of the floodplain area. The sampling points 1, 2, 3 and 4 are situated in the lower part of the hillside about $7 \mathrm{~m}$ above the water level of the Vydrica Stream and sampling points 5, 6, 7 and 8 are situated in the middle part of the hillside approximately 30 $\mathrm{m}$ above the water level of artificial ponds. The mineral component of the forest soil was classified as Dystric Cambisol.

\section{Sampling and laboratory experiments}

Soil samples were taken by sampling equipment into Kopecky cylinders with a volume of $100 \mathrm{~cm}^{3}$. We choose sampling points with a deeply developed OHFS. The OHFS contained three layers. According to the degree of decomposition of the OHFS we distinguish three layers (litter, duff-1 and duff-2). According to the world literature, the OHFS is formed of a litter layer (undecomposed organic material), a layer of duff-1 (fragmented, partially decomposed organic material) and a layer of duff- 2 (an amorphous mass, a decomposition product of organic litter) (Richard and Steven 2007 and Gerrits and Savenije 2011). The Slovak classification of soils distinguishe between the upper horizon (opadankový) and subhorizons (opad, drvina and melina) - Societas podologica Slovaca (2014). For our study, we 
have taken 24 pieces of soil samples from 8 sampling points ( 8 pieces from the litter layer, 8 pieces from the duff- 1 layer and 8 pieces from the duff- 2 layer). Afterwards, the soil samples were saturated with water. The saturation of soil samples took a long time due to the water repellency of OHFS. We let gravitational water drain from the soil samples, so that capillary water remained in the soil samples. We weighed the soil samples and quantified the SWR. We determined the SWRC for the analysis. Tempe cells and a pressure plate apparatus were used to determine points of SWRC (BS EN ISO 11274:2014, 2019). The points of the SWRC were measured with Temp cells at a pressure of $-10 \mathrm{~cm},-30 \mathrm{~cm},-50 \mathrm{~cm},-80 \mathrm{~cm},-120$ $\mathrm{cm},-150 \mathrm{~cm}$ of the water co-lumn. The pressure plate apparatus was used for determination of the SWRC point at pressures of 0.3 bar $(-300 \mathrm{~cm}), 0.6$ bar $(-600 \mathrm{~cm})$, 1.5 bar $(-1500 \mathrm{~cm})$ and 2.8 bar $(-2800 \mathrm{~cm})$. After samples had been drained on the pressure plate apparatus, they were placed into the dryer. The drying of the soil samples was at a temperature of $60^{\circ} \mathrm{C}$ to an equilibrium weight.

SWRCs are plotted from measured data using an approximation according to van Genuchten (1980) equations (1) and (2).

$$
\theta=\theta_{r}+\frac{\left(\theta_{s}-\theta_{r}\right)}{\left[1+(a h)^{n}\right]^{m}}
$$

where $\theta$ - soil water content (L3 L-3), $\theta_{r}$ - saturated soil water content (L3 L-3), $\theta_{s}$ - residual soil water content (L3 L-3), $\alpha$ - parameter (L-1), $h$ - pressure head (L), $n$ - parameter $(-)$ and $m-$ parameter $(-)$.

$$
m=1-\frac{c}{n}
$$

where $m$ - parameter $(-), c$ - parameter $(-), c=1$, based on the Mualem theory, and $n$-parameter $(-), n>1$.

The parameters of soil water retention curves $\theta_{R}, \alpha, \mathrm{n}$ were computed in the model RETC version: 6.xx (van Genuchten et al. 1991) The values of saturated hydralic conductivity (Ks) were determined in the authors' previous work (Zvala et al. 2020). The continous polygon of SWRC was estimated in MS Excel (see Fig. 3).

\section{Statistical analysis}

Differences between the SWR estimated in different layers of soil horizon were evaluated using single factor ANOVA with Tukey's Honest Significant Difference (HSD) post-hoc test. The Tukey-Kramer method (also known as Tukey's HSD method) uses the Studentized Range distribution to compute the adjustment to the critical value. The Tukey-Kramer method achieves the exact alpha level (and simultaneous confidence level $(1-\alpha)$ ) if the group sample sizes are equal and is conservative if the sample sizes are unequal. The statistical significance in the analysis was defined at $\mathrm{P}<0.05$. 


\section{RESULTS AND DISCUSSION}

According to a detailed examination of the OHFS layers, we found out that the parameters of OHFS (thickness and distribbution of layers) are not continous within the study area. There are places with higher and places with lower thickness of OHFS, or places where the OHFS is missing completely. Soil samples were taken from three identified layers of organic horizon.

The mean value of SWR values per $100 \mathrm{~cm}^{3}$ for litter, duff- 1 , duff- 2 OHFS layers (Tab. 1) were determined by the laboratory experiments. SWR increases with increasing depth in order: litter $>$ duff-1 $>$ duff- 2 . Differences in laboratory experiments were caused by different degrees of decomposition, texture and structure of OHFS, porosity and water repellency. The mean SWR value for OHFS is 73.06 $\mathrm{ml}$ of water per $100 \mathrm{~cm}^{3}$ of OHFS. The SWR affects mostly the amount of precipitation, temperature, humidity, OHFS thickness, type and granularity of the mineral component below the organic horizon, relief location, vegetation, erosion (Minár et al. 2001).

Values of the SWR of litter, duff-1 and duff-2 layer are presented in Table 1. Statistical analysis showed a significant difference $(\mathrm{P}>0.05)$ between the mean values of SWR in all three identified layers.

Tab. 1. Statistical data of the SWR of litter, duff-1 and duff-2 layers of OHFS at the Železná studnička study area. Arithmetic means with the same letter are not significantly different from each other (Tukey's HSD test, $P>0.05$ )

\begin{tabular}{lccccccc}
\hline $\begin{array}{l}\text { Organic horizon } \\
\text { layers }\end{array}$ & $\begin{array}{c}\text { Min. } \\
(\mathrm{ml})\end{array}$ & $\begin{array}{c}\text { Max. } \\
(\mathrm{ml})\end{array}$ & Skewness & Kurtosis & $\begin{array}{c}\text { SD } \\
(\mathrm{ml})\end{array}$ & $\begin{array}{c}\text { Mean } \\
(\mathrm{ml})\end{array}$ & $\mathrm{N}$ \\
\hline Litter & 74.54 & 89.22 & 0.40 & 1.74 & 5.22 & $81.22^{\mathrm{a}}$ & 8 \\
Duff-1 & 72.25 & 79.15 & 0.90 & 2.72 & 2.24 & $74.87^{\mathrm{b}}$ & 8 \\
Duff-2 & 57.73 & 71.09 & 0.50 & 1.93 & 4.77 & $63.10^{\mathrm{c}}$ & 8 \\
\hline
\end{tabular}

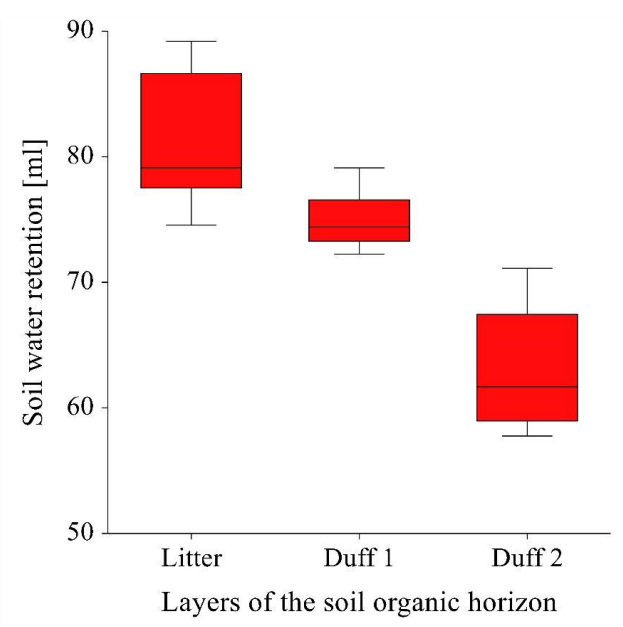

Fig. 2. Box plots presenting the measured SWR (ml) of litter, duff-1 and duff-2 layer of OHFS at the Železná studnička study area 
Eight SWRC for each layer of litter, duff-1 and duff-2 of the organic soil horizon under the deciduous forest were plotted. A total of 24 SWRCs were determined. The SWRCs for the layers of litter, duff-1 and duff- 2 in the deciduous forest are shown in Fig. 3.
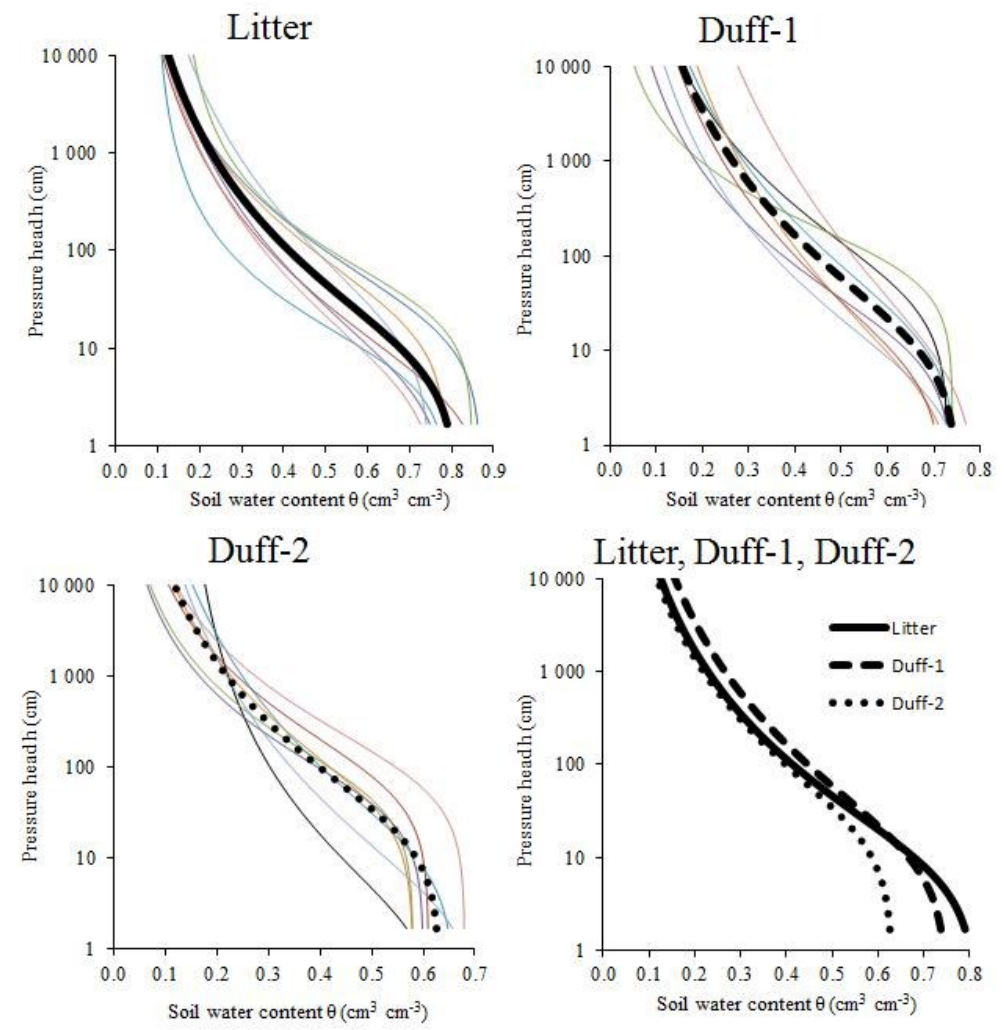

Fig. 3. SWRC for litter, duff-1 and duff-2 layers of the organic horizon at Železná studnička. SWRC marked with a bold line are the mean for the litter, duff-1 and duff-2 layers

Tab. 2. Values of van Genuchten equation parameters for average SWRC of OHFS layers litter, duff-1, duff-2

\begin{tabular}{lcccc}
\hline $\begin{array}{l}\text { Organic horizon } \\
\text { layers }\end{array}$ & $\begin{array}{c}\theta_{\mathrm{s}} \\
\left(\mathrm{L}^{3} \mathrm{~L}^{-3}\right)\end{array}$ & $\begin{array}{c}\theta_{\mathrm{r}} \\
\left(\mathrm{L}^{3} \mathrm{~L}^{-3}\right)\end{array}$ & $\begin{array}{c}\alpha \\
\left(\mathrm{L}^{-1}\right)\end{array}$ & $\begin{array}{c}\mathrm{n} \\
(-)\end{array}$ \\
\hline Litter & 0.89 & 0 & 0.13 & 1.26 \\
Duff-1 & 0.75 & 0 & 0.09 & 1.23 \\
Duff-2 & 0.63 & 0 & 0.05 & 1.27 \\
\hline
\end{tabular}

From the mean SWRC it is possible to determine a higher water content in the layer duff-1 in the range of pressure heights from $10 \mathrm{~cm}$ to $1000 \mathrm{~cm}$. The forces acting in the capillary pores created by the dynamic process of decomposition of organic matter are greater than the forces acting in the macropores in the layer litter. 
Laboratory measurements and comparison with data from the literature show that the values for the individual layers litter, duff-1, duff- 2 of the OHFS and the mean value of volume moisture graphically shown in Fig. 3 are realistic values. The work of Hlaváčiková et al. (2016) determined SWR for a forested basin of the Jalovecký Stream (Western Tatra Mts.) in values of $0.6 \mathrm{~cm}^{3} . \mathrm{cm}^{-3}$ of OHFS, covered by a coniferous forest. Values of $0.45-0.6 \mathrm{~cm}^{3} \cdot \mathrm{cm}^{-3}$ were measured (Heiskanen and Makitalo 2002) in a coniferous forest, Finnish Lapland (northern Finland), values $0.75-0.9 \mathrm{~cm}^{3} . \mathrm{cm}^{-3}$ in a coniferous forest in the federal states of Berlin and Brandenburg, Germany (Greiffenhagen et al. 2006), and Zvala et al. (2018) report values of $0.6-0.85 \mathrm{~cm}^{3} . \mathrm{cm}^{-3}$ for a coniferous forest near Kokavske lúky (Western Tatras, Slovakia). Dlapa et al. (2020) have studied a deciduous forest, located in Myjavská Pahorkatina, in southwestern Slovakia. The influence of organic matter of the OHFS on increasing the SWR of forest soil was proved. In our previous paper (Zvala et al. 2018) we measured the mean value of the mineral horizon of the same soil type as in Zelezná studnička located under OHFS. The mean SWR value for the mineral component was determined to be $63.05 \mathrm{ml}$ per $100 \mathrm{~cm}^{3}$ of mineral soil. From the comparison of mean values of SWR, we can conclude that the organic component of OHFS has bigger SWR as a mineral component. In the work of Dlapa et al. 2020, bigger values of SWR were measured for deciduous forest soil in comparison with arable land where no organic horizon was created due to cultivation. It should be noted, that the methodological procedure for determining the SWR of OHFS in laboratory conditions simulates a process of the total saturation of the organic horizon and subsequent outflow of gravitational water. Such conditions naturally occur only during very intense rains or in the spring when the forest soil is moistened by melting snow. In the natural environments organic matter is unevenly distributed. OHFS is often transported due to low weight and weather conditions and subsequently accumulated in various places. Therefore, it is common to observe places where the forest floor is completely without an organic horizon, and other places with accumulated organic matter in the form of a several centimeter thick organic horizon.

Mean SWRCs for each layer of the OHFS were determined. According to the graphic presentation in Fig. 3, it can be stated that the SWRCs of the OHFS at the individual sampling points differ from each other. The results proved the spatial variability of SWR at the sampling points. The spatial variability of the SWRis caused in this case by the thickness of the horizon and intercrown spacing, where precipitation falls directly on the forest soil as opposed to places where part of the precipitation is interceptively trapped in the treetops. The OHFS is characterized by a low input value for air, i.e. pressure at which air begins to penetrate into the saturated sample and the point where the shape of the SWRC changes (Hlaváčiková et al. 2016).

In the natural environment the volume of water that forest soil is able to retain is influenced by the amount of precipitation, temperature, humidity, thickness of the organic horizon, type and granularity of the mineral component of forest soil below the organic horizon, capillary movement of water in the mineral component of forest soil, soil water repellency, relief position, vegetation, erosion, etc. (Ištoňa and Pavlenda 2011, Hlaváčiková et al. 2016, Zvala et al. 2018 and Dlapa et al. 2020). Volumetric moisture in the forest soil is reduced by natural drainage, transpiration by vegetation and evaporation from the soil surface. 
We identified potential geotopes in Slovakia (Fig. 1a), according to the geographical parameters of the study area Železná studnička. The same geographical parameters of geotopes predetermine these localities for the development of a similar OHFS. For further generalization it is necessary to research geotopes and determine the current state of a OHFS. The OHFS changes dynamically, increasing the amount of organic matter during the year, especially during the falling of leaves and the gradual decomposition of organic matter. The obtained SWR data can be used as an input for mathematical modeling (Singh and Woolhiser 2002) in order to partially reduce the hazards and consequences of local high precipitation events.

\section{CONCLUSIONS}

The organic component of forest soil has a higher SWR as the mineral component. The analysis of the individually determined SWRCs proved that the highest value of SWR at pressure head zero was determined for the litter layer of the OHFS. The lowest value of SWR was found for the duff-2 layer. The SWR decreases with an increasing depth of the organic horizon in the order litter $>$ duff$1>$ duff- 2 .

The higher value of SWR of the individual OHFS observed during our research was caused by lower water and dissolved substances flux through the soil profile and a lower degree of soil degradation.

Geographical predisposition of a particular locality has a significant influence on the creation of the organic horizon of forest soil and the subsequent retention of water in the country. Based on the specific conditions of the study area, we identified geotopes with a similar OHFS as potential areas with similar geographical natural conditions. Further study and verification of our findings in these localities could bring more understanding to the process of SWR in these specific forest soils. Further detailed analyses are also desirable for forming input values to the more sophisticated mathematical models.

Specification of SWR OHFS in the study area Železná studnička is of practical importance for the possibility to influence e.g. vegetation management, forest establishment and retention of water in the landscape.

This publication is the result of the project implementation supported by the VEGA Grant Agency (grant number 2/0096/19 - Phytoindication of changes in soil hydrological regime).

\section{REFERENCES}

ATLAS KRAJINY SLOVENSKEJ REPUBLIKY (2002). Bratislava, Banská Bytrica (Ministerstvo životného prostredia SR a Slovenská agentúra životného prostredia).

BS EN ISO 11274:2014 (2019). Soil quality - Determination of the water - retention characteristic - Laboratory methods, [Online]. Dostupné na: http://www.standards.govt.nz/ bs-en-iso-112742019/ [cit.: 26-04-2021].

ČABOUN, V., MIND́ÁS, J. (2003). Vodná bilancia a hydrické funkcie lesných ekosystémov v krajine. Funkcia energetickej a vodnej bilancie v bioklimatických ekosystémoch. Zborník príspevkov. Nitra (SPU), [Online]. Dostupné na: http://www.cbks.cz/ sbornikRackova03/sections/4/Caboun.pdf [cit.: 29-11-2021].

ČABOUN, V., TUTKA, J., MORAVČÍK, M. (2010). Uplatňovanie funkcii lesa v krajine. Zvolen (Národné lesnícke centrum). 
DLAPA, P., HRINIK, D., HRABOVSKÝ, A., ŠIMKOVIČ, I., ŽARNOVIČAN, H., SEKUCIA, F., KOLLÁR, J. (2020). The impact of land - use on the hierarchical pore size distribution and water retention properties in loamy soils. Water, 12, 339. DOI: https://doi.org/10.3390/w12020339

GAJIC, B., DUGALIC, G., SREDOJEVIC, Z., TOMIC, Z. (2008). Efect of different vegetation types on infiltration and soil water retention. Cereal Research Communications, 36, Supplement Part II., 991-994. DOI: 10.1556/CRC.36.2008.Suppl.1

GERRITS, A. M. J., SAVENIJE, H. H. G. (2011). Interception. In Peter, W., ed. Treatise on Water Science, Oxford (Academic Press), pp. 89-101. DOI: https://doi.org/10.1016/ B978-0-444-53199-5.00029-4

GOMYO, M., KURAJI, K. (2016). Effect of the litter layer on runoff and evapotranspiration using the paired watershed method. Journal of Forest Research, 21, 306-313. DOI: https://doi.org/10.1007/s10310-016-0542-5

GREIFFENHAGEN, A., WESOLEK, G., FACKLAM, M., RENGER, M., STOFFREGEN, H. (2006). Hydraulic functions and water repellency of forest floor horizons on sandy soils. Geoderma, 132, 182-195.

HANUŠIN, J. (2002). Hydrological and geomorphological aspects of different farming practices. Geografický časopis, 54, 85-96.

HANUŠIN, J., LACIKA, J. (1997). Priestorová analýza intenzity eróznych procesov na hornom povodí Torysy. In Harčár, J., Nižňanský, B., eds. Krajina východného Slovenska v odborných a vedeckých prácach. Prešov (Východoslovenská pobočka Slovenskej geografickej spoločnosti), pp. 129-135.

HEISKANEN, J., MAKITALO, K. (2002). Soil water-retention characteristics of Scots pine and Norway spruce forest sites in Finnish Lapland. Forest Ecology and Management, 162, 137-152.

HLAVÁČIKOVÁ, H., HOLKO, L., KOSTKA, Z., DANKO, M., HLAVČO, J. (2016). Spatial and temporal variability of soil moisture in the organic horizon of a mountain forest soil. Acta Hydrologica Slovaca, 17, 265-278.

HOLKO, L., ŚKVARENINA, J., KOSTKA, Z., FRIČ, M., STAROŇ, J. (2009). Impact of spruce forest on rainfall intercepttion and seasonal snow cover evolution in the Western Tatra Mountains, Slovakia. Biologia, 64, 594-599. DOI: 10.2478/s11756- 009-0087-6, DOI: https://doi.org/10.2478/s11756-009-0087-6

ILEK, A., KUCZA, J., SZOSTEK, M. (2017). The effect of stand species composition on water storage capacity of the organic layers of forest soils, European Journal of Forest Research, 134, 187-197. DOI: https://doi.org/10.1007/s10342-014-0842-2

IŠTOŇA, J., PAVLENDA, P. (2011). Monitoring of water storage in forest soil on PMP Čifáre in the years 1999 - 2009, Forestry Journal, 57, 178-186.

JONCZAK, J. (2013). Soil organic matter properties in Stagnic Luvisols under different land use types. Acta Agrophysica, 20, 565-576.

LAPIN, M., FAŠKO, P., MELO, M., ŠŤASTNÝ, P., TOMLAIN, J. (2002). Klimatické oblasti. In Atlas krajiny SR. Bratislava, Banská Bystrica (Ministerstvo životného prostredia SR a Slovenská agentúra životného prostredia).

LEUSCHNER, C. (1998). Water extraction by tree fine roots in the forest floor of the temperate Fagus-Quercus forest. Annals of Forest Science, 55, 141-157. DOI: https:// doi.org/10.1051/forest:19980109

LI, X., NIU, J., XIE, B. (2014). The effect of leaf litter cover on surface runoff and soil erosion in Northern China. PLoS ONE, 9. e107789. DOI: https://doi.org/10.1371/ journal.pone.0107789

LI, Y., LI, B., ZHANG, X., CHEN, J. J., ZHAN, F. D., GUO, X. H., ZU, Y. Q. (2015). Differential water and soil conservation capacity and associated processes in four forestecosystems in Dianchi Watershed, Yunnan Province, China. Journal of Soil and Water Conservation, 70, 198-206. DOI: https://doi.org/10.2489/jswc.70.3.198

MAGLOCKÝ, S. (2002). Potenciálna prirodzená vegetácia. Mapa 1 : 500 000. In Atlas krajiny Slovenskej republiky. Bratislava, Banská Bystrica (Ministerstvo životného prostredia SR, Agentúra životného prostredia). 
MINÁR, J., BARKA, I., BONK, R., BIZUBOVÁ, M., ČERŇANSKÝ, J., FALŤAN, V., GAŠPÁREK, J., KOLÉNY, M., KOŽUCH, M., KUSENDOVÁ, D., MACHOVÁ, Z., MIČIAN, L., MIČIETOVÁ, E., MICHALKA, R., NOVOTNÝ, J., RUŽEK, I., ŠVEC, P., TREMBOŠ, P., TRIZNA, M., ZAŤKO, M. (2001). Geoekologický (komplexný fyzickogeografický) výskum a mapovanie vo vel'kých mierkach. Geografické spektrum 3. Bratislava (Geo-grafika).

RASOULZADEH, A., GHOORABJIRI, M. H. (2014). Comparing hydraulic properties of different forest floors. Hydrological Processes, 28, 5122-5130. DOI: https:// doi.org/10.1002/hyp.10006

RICHARD, H. W., STEVEN, W. R. (2007). Forest ecosystems. Analysis at Multiple Scales. (Third edition). Amsterdam (Academic Press). DOI: https://doi.org/10.1016/ B978-012370605-8.50009-8

SATO, Y., KUMAGAI, T., KUME, A., OTSUKI, K. (2004). Experimental analysis of moisture dynamics of litter layers - the effects of rainfall conditions and leaf shapes Hydrological Processes, 18, 3007-3018. DOI: https://doi.org/10.1002/hyp.5746

SINGH, V. P., WOOLHISER, D. A. (2002). Mathematical modelling of watershed hydrology. Journal of Hydrologic Engineering, 7, 270-292. DOI: https://doi.org/10.1061/ (ASCE)1084-0699(2002)7:4(270)

SOCIETAS PEDOLOGICA SLOVACA (2014). Morfogenetický klasifikačný systém pôd Slovenska. Bazálna referenčná taxonómia. Druhé upravené vydanie. Bratislava (NPPC - VÚPOP).

STANOVÁ, V., VALACHOVIČ, M., eds. (2002). Katalóg biotopov Slovenska. Bratislava (DAPHNE).

ŠÁLY, R., ŠURINA, B. (2002). Pôdy. Mapa 1 : 500 000. In Atlas krajiny Slovenskej republiky. Bratislava, Banská Bystrica (Ministerstvo životného prostredia SR, Agentúra životného prostredia).

Van GENUCHTEN, M. Th. (1980). A closed-form equation for predicting the hydraulic conductivity of unsaturated soils. Soil Science Society of American Journal, 44, 892898.

Van GENUCHTEN, M. Th., LEIJ, F. J., YATES, S. R. (1991). The RETC code for quantifying the hydraulic functions of unsaturated soils. EPA/600/2-91/065. Riverside (U.S. Salinity Laboratory, USDA, ARS).

VELEBNÝ, V., NOVÁK, V., SKALOVÁ, J., ŠTEKAUEROVÁ, V., MAJERČÁK, J. (2000). Vodný režim pôd. Bratislava (Vydavatel'stvo STU).

ZAGYVAI-KISS, K. A., KALICZ, P., SZILÁGYI, J., GRIBOVSKI, Z. (2019). On the specific water holding capacity of litter for three forest ecosystems in the eastern foothills of the Alps. Agricultural and Forest Meteorology, 278, 1-8. DOI: https:// doi.org/10.1016/j.agrformet.2019.107656

ZHANG, J. H., HOU, X., SHU, Q. S. (2016). Research on the hydrological effects of forest litter-fall. In Fang, Z., ed. Energy Science and Applied Technology. Proceedings of the 2nd International. Boca Ruton (CRC Press), pp. 85-87.

ZHU, H., WANG, G., YINGLANG, A., LIU, T., (2020). Ecohydrological effects of litter cover on the hillslope-scale infiltration-runoff patterns for layered soil in forest ecosystem, Ecological Engineering, 155, 105930 DOI: https://doi.org/10.1016/j.ecoleng. 2020.105930

ZVALA, A., ORFÁNUS, T., NAGY, V. (2018). Water retention in organic forest floor soil horizons under spruce stand (Picea abies). Acta Hydrologica Slovaca, 19, 162-168.

ZVALA, A., ORFÁNUS, T., ČELKOVÁ, A. (2020). The measurements of saturated hydraulic conductivity of the forest floor under deciduous forest. Acta Hydrologica Slova$c a, 21,106-112$.

ZVARA, I., GAŠPAR, A. (2002). Sklon reliéfu. Mapa 1 : 1000 000. In Atlas krajiny Slovenskej republiky. Bratislava, Banská Bystrica (Ministerstvo životného prostredia SR, Agentúra životného prostredia). 


\section{Anton Zva la, Peter Šurda, Anna Ki dová, Justína Vit ková \\ RETENCIA VODY ORGANICKÝM HORIZONTOM LISTNATÉHO LESA V STREDNEJ EURÓPE}

Organický pôdny horizont tvorí povrch lesnej pôdy pod listnatým lesom a je zložený z rôznych odumretých rastlinných a živočíšnych materiálov. Tento materiál sa postupne rozkladá na rozpoznatel'né vrstvy organického pôdneho horizontu: opad, čiastočne rozložený opad a rozložený opad. V rôznych vrstvách organického pôdneho horizontu listnatého lesa možno predpokladat' odlišnú retenciu vody. Pôdna retencia vody je pôdna voda, ktorá je zadržiavaná v pórovom systéme dlhší čas. Študovaným územím bola Zelezná studnička, na ktorom sme odobrali pôdne vzorky organického horizontu lesnej pôdy listnatého lesa.

Ciel'om príspevku bolo: a) stanovit' pôdnu retenciu vody v organických lesných horizontoch listnatého stredoeurópskeho lesa pomocou laboratórnych experimentov (tempské cely a pretlakový platňový prístroj), b) graficky a štatisticky analyzovat' získané údaje a pôdne vodoretenčné krivky a c) určit' potenciálne oblasti na Slovensku s geograficky podobnými podmienkami.

Odobratých pôdnych vzoriek z organického horizontu lesnej pôdy bolo 24 . Osem pôdnych vzoriek z vrstvy opad, osem pồdnych vzoriek z vrstvy čiastočne rozložený opad a osem pôdnych vzoriek $z$ vrstvy rozložený opad. Po saturácii pôdnych vzoriek vodou v laboratóriu sme nechali odtiect' gravitačnú vodu. Zistili sme priemernú hodnotu pôdnej vodoretencie $73,06 \mathrm{ml}$ vody na $100 \mathrm{~cm}^{3}$ organického horizontu lesnej pôdy.

Namerané hodnoty na tempských celách a pretlakovom platňovom prístroji sme spracovali na pôdne vodoretenčné krivky. Pôdne vodoretenčné krivky sme analyzovali pre každú vrstvu organického horizontu listnatej lesnej pôdy. Skúmali sme štatisticky významné rozdiely medzi všetkými tromi skúmanými vrstvami lesnej pôdy. Štatistická analýza preukázala významný rozdiel $(\mathrm{P}>0,05)$ medzi strednými hodnotami pôdnej vodoretencie vo všetkých troch vrstvách organického horizontu lesnej pôdy. Podl'a výsledkov nášho experimentu pôdna vodoretencia klesá s rastúcou hĺbkou organického horizontu nasledovne opadanka $>$ drvina $>$ melina. Vyššia vodná retenčná kapacita organického horizontu lesnej pôdy pozorovaná v príspevku môže spôsobit' nižší tok vody a rozpustených látok pôdnym profilom a nižší stupeň degradácie pôdy. Na druhej strane vodný režim je výrazne ovplyvnený evapotranspiráciou odlišnej vegetácie a intercepciou zrážok vegetáciou a lesnou pôdou.

Na základe skúmaného územia sme určili potenciálne oblasti s geograficky podobnými podmienkami pre vytvorenie organického horizontu lesnej pôdy ako na skúmanom území. Významné výsledky retencie vody organickým horizontom lesnej pôdy z lokality Železná studnička by sa dali potenciálne použit' na geotopy zobrazené na obr. 1a. Rovnaké prírodné podmienky geotopov predurčujú tieto lokality na vznik a vývoj organických horizontov lesnej pôdy. Pre d'alšie zovšeobecnenie je potrebné skúmat' geotopy a určit' súčasný stav organických horizontov. Organický horizont lesnej pôdy podlieha dynamickému procesu, ktorý zvyšuje množstvo organickej hmoty v priebehu roka najmä opadávaním listov a postupným rozkladom organických látok. Geografická predispozícia lokality má výrazný vplyv na vytvorenie organického horizontu lesnej pôdy a následné zadržiavanie vody v krajine. Na základe konkrétnych podmienok skúmaného územia sme určili geotopy na vytvorenie organického horizontu lesnej pôdy ako potenciálnej oblasti s podobným pôdnym typom, vegetačným typom a priepustnost’ou/retenčnou kapacitou. Ďalšia štúdia a overenie našich výsledkov na týchto lokalitách by mohli priniest' lepšie pochopenie procesu retenčnej kapacity v týchto konkrétnych lesných pôdach. Ďalšie podrobné analýzy sú potrebné aj na formovanie vstupných hodnôt do sofistikovanejších matematických modelov. 